\title{
A preliminary survey of the diversity of soil algae and cyanoprokaryotes on mafic and ultramafic substrates in South Africa
}

\author{
Arthurita Venter ${ }^{\mathrm{A}, \mathrm{C}}$, Anatoliy Levanets ${ }^{\mathrm{A}}$, Stefan Siebert ${ }^{\mathrm{A}}$ and Nishanta Rajakaruna ${ }^{\mathrm{A}, \mathrm{B}}$ \\ A Unit for Environmental Sciences and Management, North-West University, \\ Private Bag X6001, Potchefstroom, 2520, South Africa. \\ ${ }^{B}$ College of the Atlantic, 105 Eden Street, Bar Harbor, ME 04609, USA. \\ ${ }^{\mathrm{C} C o r r e s p o n d i n g ~ a u t h o r . ~ E m a i l: ~ 10066551 @ n w u . a c . z a ~}$
}

\begin{abstract}
Despite a large body of work on the serpentine-substrate effect on vascular plants, little work has been undertaken to describe algal communities found on serpentine soils derived from peridotite and other ultramafic rocks. We report a preliminary study describing the occurrence of algae and cyanoprokaryotes on mafic and ultramafic substrates from South Africa. Results suggest that slope and aspect play a key role in species diversity and community composition and, although low $\mathrm{pH}$, nutrients and metal content do not reduce species richness, these edaphic features also influence species composition. Further, typical soil genera such as Leptolyngbya, Microcoleus, Phormidium, Chlamydomonas, Chlorococcum and Hantzschia were found at most sites. Chroococcus sp., Scytonema ocellatum, Nostoc linckia, Chlorotetraedron sp., Hormotilopsis gelatinosa, Klebsormidium flaccidium, Pleurococcus sp. and Tetracystis elliptica were unique to one serpentine site. The preliminary survey provides directions for future research on the serpentinesubstrate effect on algal and cyanoprokaryote diversity in South Africa.
\end{abstract}

Additional keywords: algae, cryptogamic ecology, serpentine geoecology, species diversity.

\section{Introduction}

A range of soils can develop from ultramafic rocks depending on climate, time, relief, chemical composition of the parent materials as well as biotic factors, especially plants and microbes (Proctor and Woodell 1975; Cardace et al.2014). Serpentine soil is derived from serpentinite, a rock formed primarily by the hydration and metamorphic transformation of the ultramafic rock, peridotite. Ultramafic rocks can vary greatly in chemical and mineral composition and can be composed of various combinations of the minerals olivine, orthorhombic and monoclinic pyroxenes, hornblende as well as the secondary products of these minerals such as serpentine group minerals, including fibrous amphiboles and talc (Alexander et al. 2007). Serpentine soils have elevated levels of heavy metals such as nickel $(\mathrm{Ni})$ and chromium $(\mathrm{Cr})$, near-neutral to alkaline $\mathrm{pH}$ values, and calcium: magnesium (Ca: Mg) ratios <1 (Rajakaruna et al. 2009). Serpentine soils are also generally characterised by nutrient deficiencies, especially nitrogen $(\mathrm{N})$, phosphorus $(\mathrm{P})$ and potassium $(\mathrm{K})$ (Daghino et al. 2012). The distinctive chemistry of ultramafic rocks and resulting serpentine soils restricts the growth of many plants, making such sites refuges for those plants that can thrive under the serpentine influence (Alexander et al. 2007). Serpentine habitats are known to harbour high numbers of endemic plant species (Siebert et al. 2002; O'Dell and Rajakaruna 2011) and are model settings for the study of plant ecology and evolution (Harrison and Rajakaruna 2011). However, cryptogamic species (i.e. such as lichens, bryophytes, algae, cyanoprokaryotes) show low levels of edaphic endemism (Bramwell and Caujape-Castells 2011; Rajakaruna et al.2012) and appear to be broadly tolerant of substrate, resulting in wide geographic distributions and range disjunctions that frequently span more than one continent (Schuster 1983). Species with wide distributions sometimes undergo environmental modification and exhibit habitatassociated vagrant forms (i.e. morphotypes). For example, Rosentreter and McCune (1992) documented how soil, biota and climate can interact to produce partially or completely vagrant life forms in several lichen genera.

According to Belnap and Lange (2001), algae and cyanoprokaryotes can colonise almost all soil types. Terlizzi and Karlander (1979) found members of the Cyanophyceae, Chlorophyceae and Bacillariophyceae in serpentine soil samples collected at Soldiers Delight, Maryland, USA, but concluded that the composition of the soil flora at the division level is similar to that of more favourable soil types. Serpentine soil environments are comparable to metal-enriched mine tailings that include stressors such as nutrient deficiencies, unfavourable 
soil structure, water stress and toxic concentrations of metals (Reddy et al. 2001; O’Dell and Rajakaruna 2011). Orlekowsky et al. (2013) found that algae and cyanoprokaryotes are able to colonise mine tailings despite the harsh conditions and speculated that the presence of higher plants might have provided a microenvironment for the establishment of these organisms. Rosentreter and McCune (1992) found that vascular plants create windbreaks and shade, influencing moisture content and light intensity at the soil surface and creating suitable habitats for microbes. Cabala et al. (2011) concluded that crust formation in soils with a low $\mathrm{pH}$ and heavy-metal contamination is possible, but an increase in moisture and $\mathrm{pH}$ promotes algal development. According to Lukesova (2001), Bacillariophyceae and Cyanophyceae are more characteristic of alkaline environments, whereas species of Chlorophyceae can colonise more acidic soils.

Moisture is a key factor in the establishment of algae and cyanoprokaryotes. The low plant cover often associated with exposed and rocky serpentine outcrops contributes to hot and dry soil surfaces (Kruckeberg 2002), making it uninhabitable for soildwelling algae and cyanoprokaryotes. Surface temperature is also important because it regulates many ecosystem functions such as rates of $\mathrm{N}$ and carbon fixation, soil water evaporation and microbial activity (Belnap 2003). Kruckeberg (2002) proposed that the microbial biota of serpentine soil would be species poor, paralleling the scanty vegetation, but admitted that very little is known about the microbes of serpentine soils.

Since Kruckeberg (2002), numerous studies have documented the diversity of bacteria (Oline 2006; Rajkumar et al. 2008), fungi (DeGrood et al. 2005; Daghino et al. 2012; Southworth et al. 2014) and lichens (Favero-Longo et al. 2004; Rajakaruna et al. 2012) in serpentine soil, yet investigations of algae and cyanoprokaryotes in ultramafic soil (Terlizzi and Karlander 1979; Couté et al. 1999; Hauer 2008) are still scarce. The aim of the present study was to conduct a preliminary survey of the algal and cyanoprokaryote composition in mafic- and ultramaficderived soil to improve our understanding of the microbial diversity of serpentine and related soils.

\section{Materials and methods}

\section{Sampling sites}

Soil was sampled in February 2012 at different sampling localities in Mpumalanga and Limpopo provinces of South Africa (Fig. 1, Table 1). Ohrigstad sites (Sites 1 and 2, which were siliciclastic rocks and Silverton Formation) were situated on the metasediments of the Paleoproterozoic Transvaal Supergroup that forms the floor to the mafic-ultramafic Rustenburg Layered Suite of the Bushveld Igneous Complex (Clarke et al. 2009). The Bushveld Complex was formed 2000 million years ago when enormous volumes of magma intruded the upper levels of the earth crust (Clarke et al. 2009). Steelpoort sites (Sites 3 and 4) were situated on the ultramafic pyroxenite hills of the Vlakfontein Subsuite of the Rustenburg Layered Suite and the Burgersfort sites (Sites 5 and 6) on mafic hills of Kolobeng norite. The vegetation of Sites 1-6 (Table 1) had an open to dense woody layer, including woody and herbaceous shrubs, and an open to closed grass layer (Mucina and Rutherford 2006). It was found on moderate to steep mountainsides.
Sites 7 and 8 were located on amphibolites and serpentinite of the lower-most greenstone formations of the Barberton Supergroup (Norman and Whitfield 2006). These lower formations (Sites 7 and 8) are metamorphic and made up of the volcano-sedimentary Onverwacht Group that consists of ultramafic rocks that formed 3500 million years ago and minor felsic volcanic and sedimentary rocks that were deposited in an ancient marine environment (Hofmann et al. 2012). The vegetation of Sites 7 and 8 is considered herbaceous savanna with an open woody layer and dense forb and grass layer (Mucina and Rutherford 2006). It is generally associated with hilly terrain, with steep to moderate slopes.

Mean annual temperatures of the study area vary between 16.7 $\mathrm{C}$ and $18 \mathrm{C}$ and a mean annual summer rainfall ranges from 518 to $1194 \mathrm{~mm}$ (Mucina and Rutherford 2006; see Table 1).

At each site, a disposable plastic teaspoon was used to scrape soil up to a depth of $3 \mathrm{~mm}$ at three localities not more than $50 \mathrm{~m}$ apart, namely, underneath low-growing vegetation (mostly grasses), in bare soil and between rocks. A composite sample, comprising nine subsamples (teaspoons), was made for each of the eight sites and mixed thoroughly.

\section{Identification}

A combination of direct-determination and enrichment-culture techniques were used to detect cyanoprokaryotes and eukaryotic algae (Langhans et al. 2009). A direct investigation was conducted according to the method described in Lund (1945). Subsamples of $10 \mathrm{~g}$ of soil were wetted with distilled water in Petri dishes and incubated at $20 \mathrm{C}$ and a light intensity of $35 \mu \mathrm{mol} \mathrm{m} \mathrm{m}^{-2}$. Three sterile coverslips were placed on the soil in each Petri dish after $24 \mathrm{~h}$. Algal communities that established underneath the coverslips were examined and enumerated using the semiquantitative scale of Starmach (1963), which classifies algae and cyanoprokaryotes as subdominant if 30-50 specimens are present on the coverslip and dominant if more than 50 specimens are present.

The enrichment-culture techniques included the use of agar plates and liquid cultures. For the agar plates, 10-g soil subsamples were incubated on $1.5 \%$ agar plates enriched with either Bold's basal growth medium (BBM; Brown et al. 1964) as described in Stein (1973) or GBG11 growth medium (Krüger 1978), and incubated at $20 \mathrm{C}$ and a light intensity of $35 \mu \mathrm{mol} \mathrm{m} \mathrm{m}^{-2} \mathrm{~s}^{-1}$. For the liquid cultures, subsamples of $10 \mathrm{~g}$ of soil each were enriched with either $100 \mathrm{~mL}$ BBM (Stein 1973 ) or $100 \mathrm{~mL}$ GBG11 growth medium (Krüger 1978) and incubated at a temperature of $20 \mathrm{C}$ and a continuous light intensity of $15 \mu \mathrm{mol} \mathrm{m}^{-2} \mathrm{~s}^{-1}$ to stimulate the growth of algae and cyanoprokaryotes present in low concentrations. Two different growth media were used because green algal growth is enhanced by BBM (Stein 1973) and cyanoprokaryotes by GBG11 growth medium (Krüger 1978). Cyanoprokaryotes also prefer lower light intensities and this was implemented during the incubation of the cultures.

The species were identified microscopically using a Nikon $80 \mathrm{i}$ microscope with differential interference contrast, " $\mathrm{n} 60 \mathrm{X}$ Plan Apochromatic 1.4 numerical aperture (NA) oil violetcorrected with a 1.4 NA oil condenser. Literature used for identification included Ettl et al. (1999), Hindak (2008), 


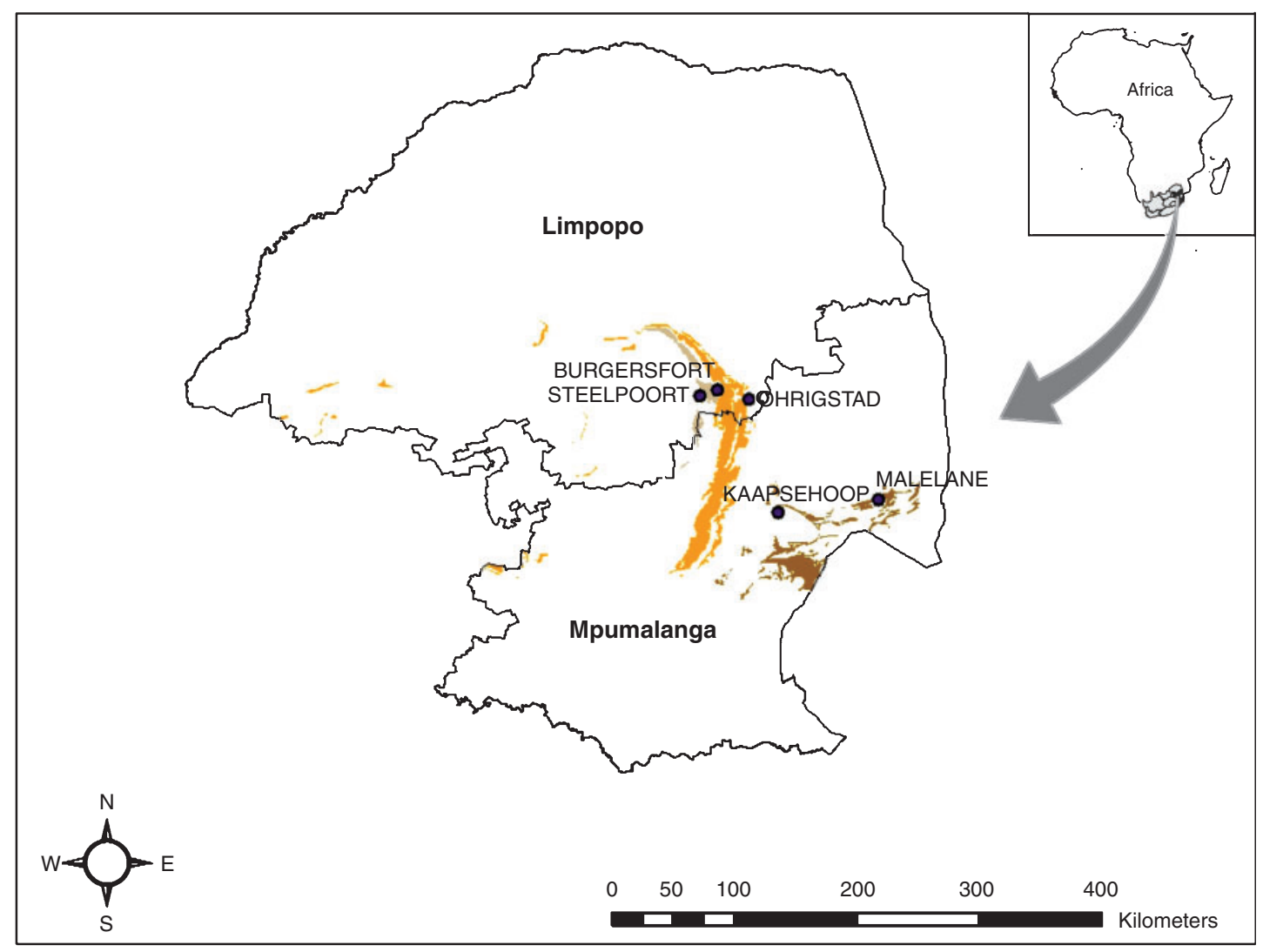

\begin{tabular}{|l|l|}
\hline Towns & Onverwacht Group, Barberton Supergroup \\
\hline Mpumalanga & Silverton Formation, Pretoria Group \\
Vlakfontein Subsuite \& Kolobeng Norite, Rustenburg Layered Suite
\end{tabular}

Fig. 1. Geology and locations of towns nearest to the sampling localities. Sites 1, 2 are near Ohrigstad, Sites 3, 4 are near Steelpoort, Sites 5, 6 are near Burgersfort, Site 7 is near Malelane, and Site 8 is near Kaapschehoop. Sites 7 and 8 are serpentinite-derived.

Hüber-Pestalozzi (1961), John et al. (2002), Komárek and Anagnostidis (2005), Taylor et al. (2007) and Wehr and Sheath (2003).

\section{Soil analyses}

At each site, the soil was randomly sampled from five of the nine subsamples per locality (minimum one and maximum two per site) and pooled to make a composite sample. The soil analysis was performed in accordance with the standards set out by the control schemes of the Agricultural Laboratory Association of Southern Africa and the International Soil Analytical Exchange (ISE), Wageningen, The Netherlands. Exchangeable $\mathrm{Ca}, \mathrm{Mg}, \mathrm{K}$ and sodium $(\mathrm{Na})$ were estimated by $1 \mathrm{M}$ ammonium acetate $(\mathrm{pH}=7), \mathrm{P}$ was estimated by $\mathrm{P}$-Bray 1 extraction, $\mathrm{pH}$ was estimated via $1: 2.5$ extraction and electrical conductivity (EC) was determined with a saturated extraction. These methods followed NSSSA (1990). All heavy metals, including aluminium $(\mathrm{Al})$, arsenic (As), cadmium $(\mathrm{Cd})$, cobalt $(\mathrm{Co})$, copper $(\mathrm{Cu}), \mathrm{Cr}$, iron $(\mathrm{Fe})$, mercury $(\mathrm{Hg})$, manganese $(\mathrm{Mn})$, molybdenum (Mo), $\mathrm{Ni}$, lead $(\mathrm{Pb})$ and vanadium $(\mathrm{V})$, as well as $\% \mathrm{~N}$ and $\% \mathrm{~S}$ were estimated by EPA Method 3050b (US EPA 1996).

\section{Data analysis}

Statistica version 12 software (StatSoft Inc., Tulda, OK, USA) was used to perform Student's $t$-tests to determine whether the data from one site differed significantly $(P<0.5)$ from those from another site. The algal composition of a site was compared with the algal composition of another site and repeated until each site was compared with all the other sites. The approach was also repeated for the edaphic features of each site. Similarities among the species compositions of the different sites were analysed by using the Bray-Curtis dissimilarity index (Hahs and McDonnell 2006). This was performed with the software program Primer 5 (Clarke and Gorley 2001). CANOCO version 4.5 software (Cambridge University Press, Cambridge, UK) was used to perform principal component analysis (PCA) on the chemical variables of the different sites. Canonical correspondence analysis (CCA) was performed on the species data as well as the chemical variables (Table 2), which included the Monte Carlo permutation test for significance (Ter Braak and Smilauer 1998). The species matrix for the analysis was compiled by allocating values to the species that were absent (0), present (1) subdominant (2) and dominant (3). 


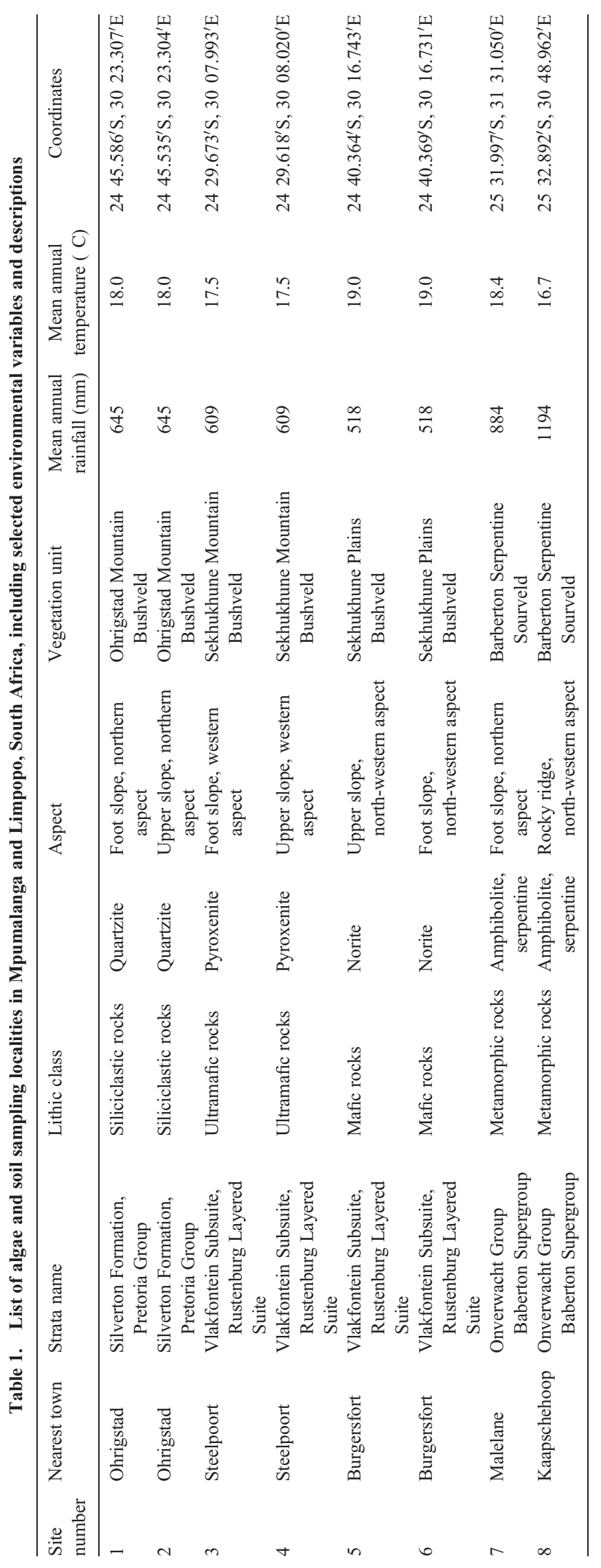


Table 2. Chemical characteristics for composite soil samples collected from the eight sites

EC, electrical conductivity; CEC, cation exchange capacity

\begin{tabular}{|c|c|c|c|c|c|c|c|c|}
\hline Soil characteristic & Site 1 & Site 2 & Site 3 & Site 4 & Site 5 & Site 6 & Site 7 & Site 8 \\
\hline $\mathrm{pH}\left(\mathrm{H}_{2} \mathrm{O}\right)$ & 6.27 & 5.54 & 6.46 & 6.36 & 6.86 & 6.31 & 7.61 & 5.91 \\
\hline $\mathrm{pH}(\mathrm{KCl})$ & 5.31 & 4.81 & 5.21 & 5.49 & 6.15 & 5.38 & 6.8 & 5.34 \\
\hline $\mathrm{EC}\left(\mathrm{mS} \mathrm{m}^{-1}\right)$ & 23 & 31 & 28 & 31 & 58 & 39 & 55 & 10 \\
\hline $\mathrm{CEC}\left(\operatorname{cmol}(+) \mathrm{kg}^{-1}\right)$ & 11.44 & 13.49 & 24.68 & 25.20 & 25.95 & 25.18 & 18.39 & 3.76 \\
\hline$\%$ Base saturation & 66.25 & 48.01 & 54.36 & 67.84 & 93.17 & 72.14 & 109.4 & 46.9 \\
\hline \multicolumn{9}{|l|}{ Macronutrients } \\
\hline Calcium $(\mathrm{Ca})\left(\operatorname{cmol}(+) \mathrm{kg}^{-1}\right)$ & 5.07 & 3.49 & 5.82 & 6.17 & 14.61 & 8.4 & 8.22 & 0.36 \\
\hline Magnesium $(\mathrm{Mg})\left(\mathrm{cmol}(+) \mathrm{kg}^{-1}\right)$ & 1.98 & 2.23 & 11.25 & 10.65 & 9.06 & 9.18 & 11.51 & 1.36 \\
\hline $\mathrm{Ca}: \mathrm{Mg}$ ratio & 2.56 & 1.57 & 0.52 & 0.58 & 1.61 & 0.92 & 0.71 & 0.26 \\
\hline Potassium (K) $\left(\mathrm{mg} \mathrm{kg}^{-1}\right)$ & 195.5 & 281 & 102.9 & 95 & 188.5 & 218 & 136.5 & 1.5 \\
\hline Sodium $(\mathrm{Na})\left(\mathrm{mg} \mathrm{kg}^{-1}\right)$ & 6 & 8 & 7 & 7 & 6 & 7 & 9 & 9 \\
\hline Phosphorus (P) (mg kg $\left.{ }^{-1}\right)$ & 3.6 & 4.3 & 21.2 & 10.8 & 3.9 & 37.7 & 4.2 & 1.7 \\
\hline$\%$ Nitrogen & 0.46 & 0.44 & 0.52 & 0.49 & 0.58 & 0.63 & 0.47 & 0.4 \\
\hline$\%$ Sulfur & 0.21 & 0 & 0.01 & 0.01 & 0 & 0.04 & 0 & 0.01 \\
\hline \multicolumn{9}{|c|}{ Micronutrients and heavy metals $\left(\mathrm{mg} \mathrm{kg}^{-1}\right)$} \\
\hline Aluminium & 2746 & 3514 & 826 & 921 & 1959 & 1514 & 1555 & 3021 \\
\hline Arsenic & 0.08 & 0.1 & 0.1 & 0.08 & 0.07 & 0.15 & 0.43 & 4.06 \\
\hline Cadmium & 0.001 & 0.001 & 0.01 & 0.001 & 0.0008 & 0.003 & 0.0008 & 0.0009 \\
\hline Cobalt & 1.38 & 1.79 & 3.48 & 3.92 & 2.2 & 4.79 & 3.78 & 15.14 \\
\hline Copper & 1.17 & 1.53 & 0.85 & 0.6 & 1.74 & 1.26 & 4.35 & 8.31 \\
\hline Chromium & 6.26 & 7.94 & 85.29 & 93.97 & 32.45 & 124.4 & 55.42 & 134.2 \\
\hline Iron & 3098 & 3733 & 3832 & 3377 & 2271 & 4701 & 4274 & 8814 \\
\hline Mercury & 0.0004 & 0.0007 & 0.0046 & 0.0005 & 0.0002 & 0.0004 & 0.0006 & 0.0004 \\
\hline Manganese & 47.33 & 60.21 & 60.35 & 78.73 & 51.68 & 108.8 & 93.6 & 167 \\
\hline Molybdenum & 0.02 & 0.03 & 0.03 & 0.02 & 0.02 & 0.04 & 0.02 & 0.04 \\
\hline Nickel & 4.02 & 5.03 & 36.25 & 29.88 & 17.48 & 31.27 & 33.86 & 48.33 \\
\hline Palladium & 0.01 & 0.02 & 0.01 & 0.01 & 0.01 & 0.02 & 0.02 & 0.03 \\
\hline Vanadium & 8.51 & 10.11 & 4.24 & 3.39 & 4.63 & 5.21 & 7.96 & 20.62 \\
\hline
\end{tabular}

\section{Results}

\section{Soil analyses}

All soils were slightly acidic, except for serpentine Site 7 where a $\mathrm{pH}\left(\mathrm{H}_{2} \mathrm{O}\right)$ of 7.61 was reported (Table 2). The highest concentrations of $\mathrm{K}$ and $\mathrm{Al}$ were measured at the upper slope of the siliciclastic soils at Ohrigstad (Site 2) and the highest concentrations of $\mathrm{Cd}$ and $\mathrm{Hg}$ were measured at the foot-slope site near Steelpoort (Site 3). Burgersfort mafic soils had the highest concentrations of $\mathrm{Ca}$ (Site 5) and $\mathrm{P}$ (Site 6).

The first two axes of the PCA of the soil characteristics and the sampling sites explained $71.6 \%$ of the total variance (Fig. 2). It showed a clear association of heavy metals such as As, Co, $\mathrm{Cu}, \mathrm{Cr}, \mathrm{Fe}, \mathrm{Mn}, \mathrm{Mo}, \mathrm{Ni}, \mathrm{Pd}$ and $\mathrm{V}$ with the serpentine site at Kaapschehoop (Site 8) that also features other characteristics of serpentine soils such as low concentrations of essential nutrients, including a $\mathrm{Ca}: \mathrm{Mg}$ ratio of $<1$. This was substantially lower than for other ultramafic and mafic rocks (Sites $3,4,6)$ with ratios $<1$. All mafic and ultramafic sites had heavy-metal (mostly $\mathrm{Ni}$ ) concentrations exceeding those of the sedimentary rocks and comparable to concentrations found at the two serpentine sites.

The cation exchange capacity (CEC) of the serpentine soil at Site 8 was the lowest among the sites $\left(3.76 \mathrm{cmol}(+) \mathrm{kg}^{-1}\right)$. This is below the minimum standard of $8 \mathrm{cmol}(+) \mathrm{kg}^{-1}$ proposed for agricultural top soil in South Africa by the Soil Classification Working Group (1991). The EC of Site 8 soil was low compared to the other sites, likely resulting from low $\mathrm{K}$ concentrations present at this site.

A Student's $t$-test indicated that the edaphic features (see Table 2 for soil features tested) of the siliciclastic Site 2 and the serpentine Site 8 differ significantly $(P=0.001)$. Sites 1,2 and 8 had the highest concentrations of $\mathrm{Al}$, a known soil toxin in South Africa, but the $\mathrm{pH}$ of Site 2 and Site 8 was lower (5.54 and 5.91, respectively) than the $\mathrm{pH}$ of Site 1 (6.27), which could play a role in the bioavailability of heavy metals. For instance, at an acidic $\mathrm{pH}, \mathrm{Al}$ exists only in one oxidation state $(+3)$ and can react with other matter in the environment to form various complexes (ATSDR 2008).

\section{Algal diversity}

Site 1 had the highest number of species (24), followed by serpentine Sites 7 (22) and 8 (20) (Table 3). The lowest number of species (6) was found on the pyroxenite-derived soil at Site 3. Cyanophyceae diversity was highest at Sites 1, 4, 7 and 8 and dominated at all sites except at Site 3 where Hantzschia amphioxys (Bacillariophyceae) was the dominant algae. Leptolyngbya sp. was dominant at Sites 1, 4, 5, 7 and 8 and subdominant at Site 6. Phormidium was dominant at Sites 2, 4, 5 and 7 and subdominant at Sites 3,6 and 8. Microcoleus sp. was subdominant in the siliciclastic sites near Burgersfort (Sites 1,2) as well as the serpentine sites (Sites 7 and 8), and dominant at the mafic site near Burgersfort (Site 6). Leptolyngbya foveolarum, 


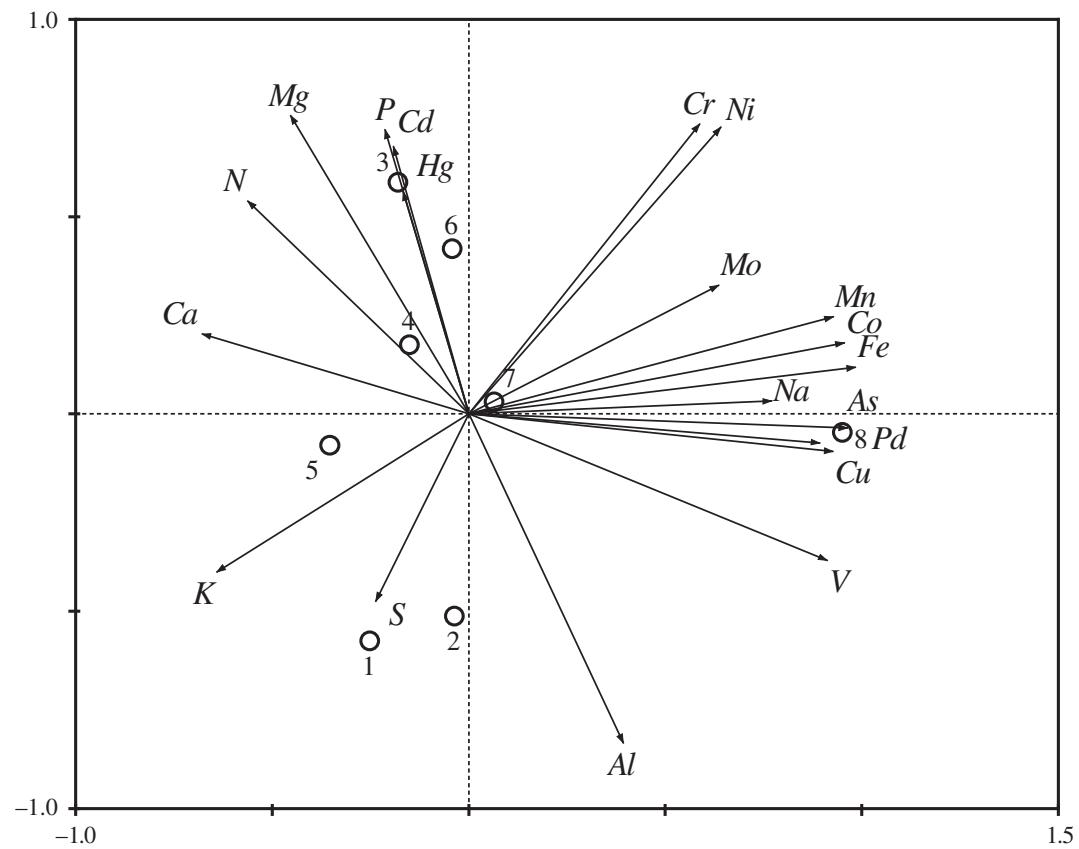

Legend: $\bigcirc$ sites; $\rightarrow$ environmental variables

Axis

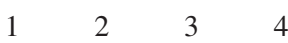

Eigen values

$\begin{array}{llll}0.48 & 0.235 & 0.093 & 0.091\end{array}$

Cumulative percentage variance:

Of species

$\begin{array}{llll}48 & 71.6 & 80.8 & 90\end{array}$

Fig. 2. Principal component analysis (PCA) to show the relationship between soil characteristics and the sampling sites.

Phormidium ambiguum and Hantzschia amphioxys were found at all sites. Chlorophyceae was the most diverse group, with the highest diversity at Site 1, whereas Bacillariophyceae diversity was the highest at Sites 1, 4 and 5. The Cyanophyceae, Chlorophyceae and Bacillariophyceae were represented at every site. However, Eustigmatophyceae did not occur at Sites 3 and 4 and the Xantophyceae occurred only at Sites 2, 6 and 7.

\section{Preliminary correlations between edaphic features and algal diversity}

Multivariate analysis confirms the strong association of heavy metals with the serpentine soils at Site 8 (Figs 2, 3). The first two axes of the CCA (Fig. 3) explained only $36.2 \%$ of the variance. Variables with high inflation factors $(\mathrm{Ca}, \mathrm{Mg}, \mathrm{P}$ and $\mathrm{N}$ ) were removed to improve the analysis, but eigenvalues or the explanation of the total variance did not change. The forward selection of factors lowered the $P$-value; however, it was still not significant, so we kept all the variables. Even with the low values, the CCA helps to visualise the species distribution with respect to the different sites, and presents preliminary information on how different edaphic features are correlated with algal diversity. Hormotilopsis gelatinosa, Klebsormidium flaccidum, Pleurococcus species, Chlorotetraedron species and Tetracystis elliptica belonging to the Chlorophyceae, and Chroococcus species, Scytonema ocellatum, Nostoc linckia as well as an unknown Nostoc species from the Cyanophyceae were closely associated with Site 8 (Fig. 3). High concentrations of K were associated with the upper slope of the sedimentary soils in Ohrigstad (Site 2; Figs 2, 3) as well as the green algae Characiopsis minima, Chlamydomonas macrostellata, Bumilleriopsis filiformis from the Xanthophyceae and the cyanoprokaryote Oscillatoria raoi. Calcium, $\mathrm{Mg}, \mathrm{S}$ and $\mathrm{N}$ appear to play a role in the similarity in species composition of Sites 1, 3, 4 and 5 .

Bray-Curtis dissimilarity index (Hahs and McDonnell 2006) grouped samples from lower slopes (Sites 1, 6 and 7; indicated with black square in Fig. 3), whereas the other sites were scattered (stress value 0.05). Cyanoprokaryotes such as Leptolyngbya foveolarum, Microcoleus vaginatus and Phormidium ambiguum, Chlorophyceae such as Chlamydomonas and Chlorococcum species, Eustigmatophyceae such as Eustigmatos magnus and Hantzschia amphioxys from Bacillariophyceae occurred on all the lower-slope sites (Sites 1, 6 and 7), but were not unique to these sites. The cyanoprokaryote Phormidium ambiguum was dominant in all the upper-slope sites (Sites 2, 4 and 5). It was interesting that the serpentine sites (Sites 7 and 8) did not form a group. Nor did the mafic and ultramafic sites (Sites 3, 4, 5 and 6) or siliciclastic sites (Sites 1 and 2). This random pattern, with a lack of grouping for sites, showed that slope position (upper vs lower) had a larger effect on 
Table 3. Algae and cyanoprokaryotes identified from the different soil samples collected from the eight sites dom, dominant; s/dom, subdominant; +, present

\begin{tabular}{|c|c|c|c|c|c|c|c|c|c|}
\hline \multirow[t]{2}{*}{ Species } & \multirow{2}{*}{$\begin{array}{l}\text { Abbreviations } \\
\text { used in Fig. } 3\end{array}$} & \multicolumn{2}{|c|}{ Siliciclastic rocks } & \multicolumn{4}{|c|}{ Mafic and ultramafic rocks } & \multicolumn{2}{|c|}{ Serpentine } \\
\hline & & Site 1 & Site 2 & Site 3 & Site 4 & Site 5 & Site 6 & Site 7 & Site 8 \\
\hline \multicolumn{10}{|l|}{ Cyanophyceae } \\
\hline Chroococcus sp. & Chro & & & & & & & & + \\
\hline Komvophoron cf. schmidlei (Jaag) & Kom & + & & & & & & & \\
\hline \multicolumn{10}{|l|}{ Anagnostids et Komárek } \\
\hline $\begin{array}{l}\text { Leptolyngbya foveolarum (Rabenhorst } \\
\text { ex Gomont) Anagnostidis } \\
\text { et Komárek }\end{array}$ & Lepto & dom & + & + & dom & dom & $\mathrm{s} / \mathrm{dom}$ & dom & dom \\
\hline Lyngbya major Meneghini & Lyn1 & + & & + & & + & & & \\
\hline Lyngbya cf. truncicola Ghose & Lyn2 & & & & + & & & & \\
\hline Microcoleus vaginatus (Vauch.) Gom. & Micro & s/dom & s/dom & & & & dom & $\mathrm{s} /$ dom & s/dom \\
\hline Nostoc commune Vauch. sensu Elenk. & Nos1 & & & + & & & & & \\
\hline $\begin{array}{l}\text { Nostoc linckia (Roth.) Born. et Flah. } \\
\text { in sensu Elenk. }\end{array}$ & Nos2 & & & & & & & & $\mathrm{s} / \mathrm{dom}$ \\
\hline Nostoc punctiforme (Kütz.) Hariot & Nos3 & & & & & & & + & \\
\hline Nostoc sp. & Nos4 & & & & & & & & + \\
\hline Oscillatoria limosa Ag. & Osc1 & & & & + & & & + & \\
\hline Oscillatoria raoi De Toni & Osc2 & & + & & & & & & \\
\hline Phormidium ambiguum Gomont & Phol & + & dom & s/dom & dom & dom & $\mathrm{s} / \mathrm{dom}$ & dom & s/dom \\
\hline $\begin{array}{l}\text { Phormidium animale (Agardh ex } \\
\text { Gomont) Anagnostidis et Komárek }\end{array}$ & Pho2 & & & & + & & & & \\
\hline $\begin{array}{l}\text { Phormidium cf. corium (Ag.) Kütz. } \\
\text { ex Gomont }\end{array}$ & Pho3 & & & & & & + & & \\
\hline Phormidium cf. jenkelianum Schmid & Pho4 & & & & & + & & & \\
\hline Phormidium jadinianum Gomont & Pho5 & & & & + & & & & \\
\hline $\begin{array}{l}\text { Phormidium mucicola Naum. et Hub.- } \\
\text { Pestalozzi }\end{array}$ & Pho6 & & & & & & + & & \\
\hline $\begin{array}{l}\text { Pseudanabaena cf. minima (G.S.An) } \\
\text { Anagnostidis }\end{array}$ & Pseu1 & & & & + & & & & \\
\hline $\begin{array}{l}\text { Pseudanabaena frigida (Fritsch) } \\
\text { Anagnostidis }\end{array}$ & Pseu2 & & & & & & & + & \\
\hline Pseudanabaena sp. & Pseu3 & + & & & + & & & + & \\
\hline $\begin{array}{l}\text { Scytonema myochrous (Dillw.) Ag. } \\
\text { ex Born. et Flah. }\end{array}$ & Scyt1 & & & & & & & + & dom \\
\hline Scytonema ocellatum Born. et Flah. & Scyt2 & & & & & & & & dom \\
\hline Scytonema sp. & Scyt3 & + & & & & & & & \\
\hline Synechocystis crassa Woronich. & Syn & & & & + & & & & \\
\hline Total Cyanophyceae & & 7 & 4 & 4 & 9 & 4 & 5 & 8 & 8 \\
\hline \multicolumn{10}{|l|}{ Chlorophyceae } \\
\hline $\begin{array}{l}\text { Bracteacoccus cf. grandis Bischoff } \\
\text { et Bold }\end{array}$ & Brac1 & + & & & & & & & \\
\hline Bracteacoccus minor (Chod.) Petrová & Brac2 & + & & & & & & & \\
\hline Bracteacoccus sp. & Brac3 & & & & & & & + & \\
\hline Characiopsis minima Pascher & Chara & & + & & & & & & \\
\hline Chlamydomonas macrostellata Lund & Chlamy & & $\mathrm{s} / \mathrm{dom}$ & & & & & & \\
\hline Chlamydomonas sp.1 & Chlam1 & + & + & & + & & + & + & + \\
\hline Chlamydomonas sp. 2 & Chlam2 & & & & + & & & & \\
\hline Chlorella munitissima Fott et Nováková & Chlo1 & + & & & & & & & \\
\hline Chlorella vulgaris Beijerinck & Chlo2 & + & & & & $\mathrm{s} / \mathrm{dom}$ & + & & \\
\hline Chlorella sp. & Chlo3 & & & & & + & & + & \\
\hline Chlorococcum echinozygotum Starr & Chlc1 & s/dom & & & & & & & \\
\hline $\begin{array}{l}\text { Chlorococcum infusionum (Schrank) } \\
\text { Meneghini }\end{array}$ & Chlc2 & + & & & + & + & + & + & \\
\hline $\begin{array}{l}\text { Chlorococcum oviforme Archibald } \\
\text { et Bold }\end{array}$ & Chlc3 & & & & & & + & & \\
\hline Chlorococcum vacuolatum Starr & Chlc4 & & & & & + & & & \\
\hline Chlorococcum sp.1 & Chlc5 & + & + & & & & & & \\
\hline Chlorococcum sp.2 & Chlc6 & + & & & + & & + & + & + \\
\hline
\end{tabular}


Table 3. (continued)

\begin{tabular}{|c|c|c|c|c|c|c|c|c|c|}
\hline \multirow[t]{2}{*}{ Species } & \multirow{2}{*}{$\begin{array}{l}\text { Abbreviations } \\
\text { used in Fig. } 3\end{array}$} & \multicolumn{2}{|c|}{ Siliciclastic rocks } & \multicolumn{4}{|c|}{ Mafic and ultramafic rocks } & \multicolumn{2}{|c|}{ Serpentine } \\
\hline & & Site 1 & Site 2 & Site 3 & Site 4 & Site 5 & Site 6 & Site 7 & Site 8 \\
\hline $\begin{array}{l}\text { Chlorosarcinopsis aggregata Arce } \\
\text { et Bold }\end{array}$ & Chls1 & & & + & & & & & \\
\hline Chlorosarcinopsis minor (Gerneck) & Chls2 & & & & & $\mathrm{s} / \mathrm{dom}$ & + & + & \\
\hline \multicolumn{10}{|l|}{ Herndon } \\
\hline Chlorotetraedron sp. & Chlt & & & & & & & & + \\
\hline $\begin{array}{l}\text { Hormotilopsis gelatinosa Trainor } \\
\text { et Bold }\end{array}$ & Hormo & & & & & & & & + \\
\hline Interfilum sp. & Inter & & + & & & & & + & \\
\hline $\begin{array}{l}\text { Klebsormidium flaccidum (Kütz.) } \\
\text { P.C.Silva, Mattox et W.H.Blackwell }\end{array}$ & Kleb & & & & & & & & + \\
\hline $\begin{array}{l}\text { Myrmecia biatorellae (Tschermak- } \\
\text { Woess) J.B.Petersen }\end{array}$ & Myrm & & & & & & & + & \\
\hline Pleurococcus & Pleur & & & & & & & & + \\
\hline Scenedesmus sp. & Scene & + & & & & & & & \\
\hline Scotiellopsis rubescens Vinatzer & Scot 1 & & & & + & & & & \\
\hline Scotiellopsis terrestris (Reisigl) & $S \cot 2$ & & & & + & & + & & + \\
\hline \multicolumn{10}{|l|}{ Punčochár ová et Kalina } \\
\hline Spongiochloris sp.1 & Spong1 & & & & & & + & & + \\
\hline Spongiochloris sp.2 & Spong2 & + & + & & & & & + & \\
\hline Tetracystis aggregata Brown et Bold & Tetra1 & & + & & + & & & & \\
\hline Tetracystis elliptica Nakano & Tetra2 & & & & & & & & + \\
\hline Tetracystis sp. & Tetra3 & + & & & & & & + & \\
\hline Total Chlorophyceae & & 12 & 7 & 1 & 7 & 5 & 8 & 10 & 9 \\
\hline \multicolumn{10}{|l|}{ Eustigmatophyceae } \\
\hline $\begin{array}{l}\text { Eustigmatos magnus (J.B.Petersen) } \\
\text { Hibberd }\end{array}$ & Eust & + & + & & & & + & s/dom & + \\
\hline $\begin{array}{l}\text { Monodopsis subterranea (J.B.Petersen) } \\
\text { Hibberd }\end{array}$ & Mono & & & & & + & & & + \\
\hline Total Eustigmatophyceae & & 1 & 1 & 0 & 0 & 1 & 1 & 1 & 2 \\
\hline \multicolumn{10}{|l|}{ Xantophyceae } \\
\hline Botrydiopsis arhiza Borzi & Botry1 & & & & & & & s/dom & \\
\hline Botrydiopsis sp. & Botry2 & & & & & & + & & \\
\hline Bumilleriopsis filiformis Vischer & Bum1 & & s/dom & & & & & & \\
\hline Total Xantophyceae & & 0 & 1 & 0 & 0 & 0 & 1 & 1 & 0 \\
\hline \multicolumn{10}{|l|}{ Bacillariophyceae } \\
\hline Amphora veneta Kützing & Amph1 & & & & & + & & & \\
\hline Pinnularia borealis Ehrenberg & Pin & + & & & + & $\mathrm{s} /$ dom & & & \\
\hline Navicula mutica Kützing & Nav1 & + & & & + & & & & \\
\hline Navicula pelliculosa (Kützing) Hilse & Nav2 & & & & & + & & + & \\
\hline Navicula veneta Kützing & Nav3 & + & & & & & & & \\
\hline $\begin{array}{l}\text { Hantzschia amphioxys (Ehrenberg) } \\
\text { Grunow }\end{array}$ & Hant & + & s/dom & dom & s/dom & $\mathrm{s} / \mathrm{dom}$ & + & + & + \\
\hline Total Bacillariophyceae & & 4 & 1 & 1 & 3 & 4 & 1 & 2 & 1 \\
\hline Total species richness & & 24 & 14 & 6 & 19 & 14 & 16 & 22 & 20 \\
\hline
\end{tabular}

diversity. Cyanoprokaryote species were less associated with the foot slope of pyroxenite--magnesium rich soil in Steelpoort (Site 3), with a Student's $t$-test supporting a significant difference from those at Sites $1(P=0.03), 4(P=0.03), 7(P=0.007)$ and 8 $(P=0.01)$. The pattern also showed that the lithic class may be less important than the slope position, in determining the algal and cyanoprokayote species present at the sites.

\section{Discussion}

It is widely reported that cyanoprokaryotes are well adapted to a wide range of environmental conditions and have an ability to grow on a variety of substrates, such as mine tailings (Lukesova 2001; Orlekowsky et al. 2013), barren artic soils (Michaud et al. 2012), arid regions (Řeháková et al. 2011; Mühlsteinová et al. 2014) and alkaline and serpentinising springs (Blank et al. 2009; Suzuki et al. 2013). Our preliminary study documented that cyanoprokaryotes and algae are found on mafic and ultramafic soils in South Africa and that slope position plays a role in species composition. Leptolyngbya foveolarum, Microcoleus vaginatus, Phormidium ambiguum, Chlamydomonas, Chlorococcum, Eustigmatos magnus as well as Hantzschia amphioxys were present on all three foot-slope sites at Ohrigstad, Burgersfort and Malelane (Sites 1, 6 and 7). Environmental conditions such as 


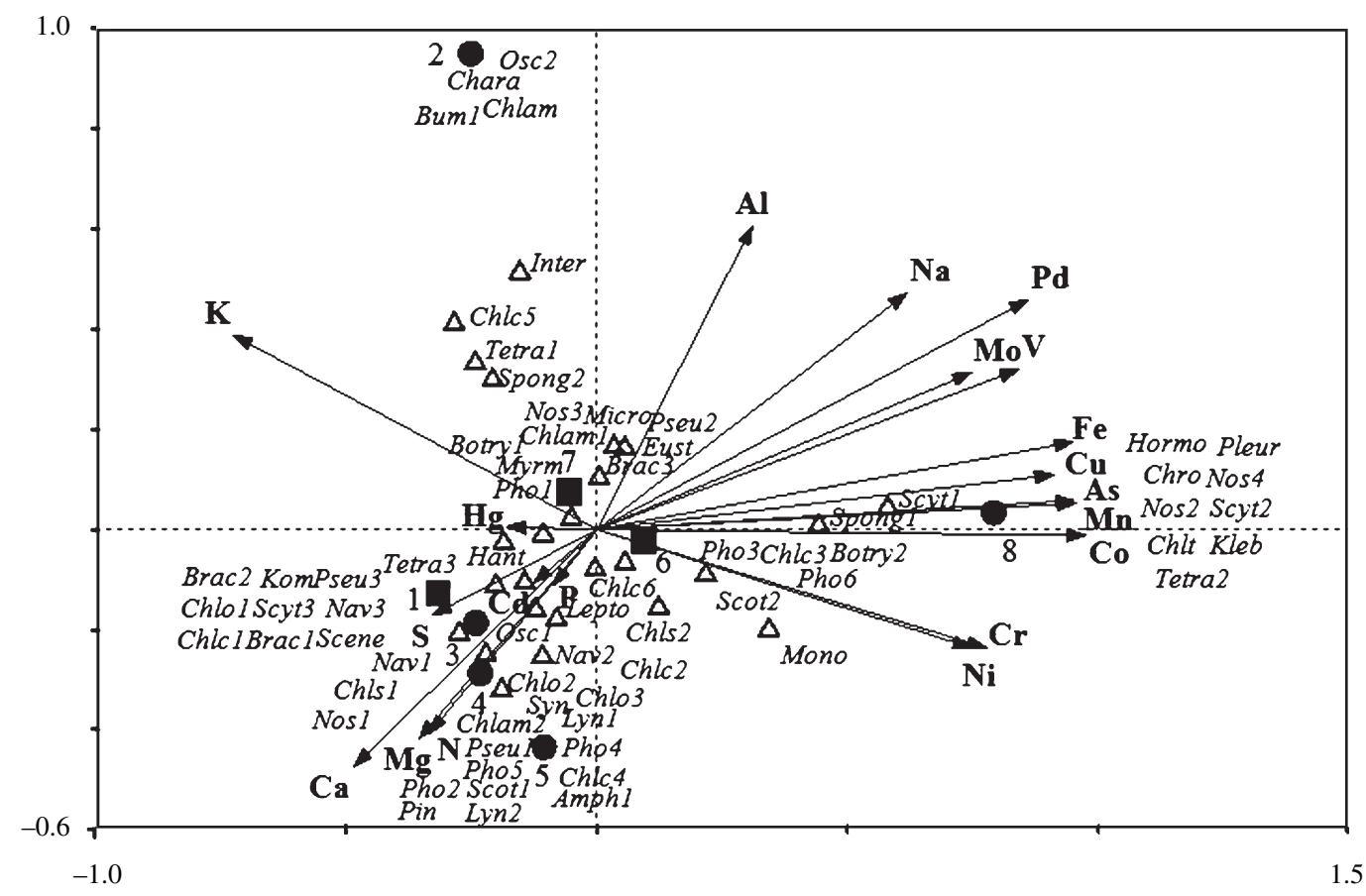

\begin{tabular}{lcccc} 
Legend: $\Delta$ species; $\bullet$ and $\bullet$ sites; $\rightarrow$ & \multicolumn{4}{c}{ environmental variables } \\
Axis & 1 & 2 & 3 & 4 \\
Eigen values & 0.52 & 0.411 & 0.388 & 0.368 \\
Cumulative percentage variance: & & & & \\
Of species & 20.2 & 36.2 & 51.3 & 65.6 \\
Of environmental relations & 20.2 & 36.2 & 51.3 & 65.6
\end{tabular}

Test of significance of first canonical axes $\mathrm{p}=1.0$

Test of significance of all canonical axes $\mathrm{p}=1.0$

Fig. 3. Canonical correspondence analysis (CCA) of metal concentrations and algal and cyanoprokaryote species of the different sampling sites. Abbreviations of species are given in Table 3.

an increase in soil moisture as a result of runoff and the accumulation of organic matter (Chen et al. 2007) could have played a role in the assembly of certain species on foot slopes. The cyanoprokaryotes Leptolyngbya foveolarum and Phormidium ambiguum were also present at the foot slope of the Mg-rich pyroxenite soil (Site 3), whereas Microcoleus vaginatus, Chlamydomonas, Chlorococcum and Eustigmatos magnus did not occur at this site. The absence of these algae as well as the low diversity observed at Site 3 could be the result of the high concentrations of $\mathrm{Cd}\left(0.01 \mathrm{mg} \mathrm{kg}^{-1}\right)$ and $\mathrm{Hg}\left(0.0046 \mathrm{mg} \mathrm{kg}^{-1}\right)$ measured at this site. According to Fernandez-Piñas et al. (1995), $\mathrm{Cd}$ induces progressive disorganisation and degradation of thylakoid membranes as well as a decrease in the mobilisation of the polyphosphate granules leading to phosphorus starvation. Pinto et al. (2003) showed that $\mathrm{Cd}$ and $\mathrm{Hg}$ inhibit photosynthesis. However, further experimentation is clearly needed to determine whether $\mathrm{Cd}$ and $\mathrm{Hg}$ were responsible for the reduced diversity observed at this site.
Most of the cyanoprokaryotes were represented by filamentous species such as Leptolyngbya foveolarum, Microcoleus vaginatus and Phormidium ambiquum, and were found at all eight sampling sites. These filamentous cyanoprokaryotes can wind throughout the uppermost soil layers, forming a net-like structure that binds together soil particles (Rosentreter et al. 2007). This forms soil aggregates that create pathways for water infiltration and surfaces for nutrient transformations, while also increasing the soil resistance to wind and water erosion. Once the filamentous cyanoprokaryotes stabilise the soil, single-celled cyanoprokaryotes such as Synechocystis sp. are able to colonise the substrate (Rosentreter et al. 2007). The Chlorophyceae, represented by mainly coccoid species such as Chlamydomonas and Chlorococcum, were found on all the sites except at Site 3. Chlorococcum echinozygotum and Chlamydomonas macrostella were subdominant on the siliciclastic-derived soils of Sites 1 and 2, respectively. Bacillariophyceae, such as Hantzschia amphioxys, was found on all the sites and was subdominant at Sites 2, 4 and 5 
and dominant at Site 3. According to Metting (1981), Leptolyngbya, Microcoleus, Phormidium, Chlamydomonas, Chlorococcum and Hantzschia species are all typical cosmopolitan soil algae.

Shields and Durell (1964) and Starks and Shubert (1982) suggested that the species composition of soil algal populations is affected less by the chemical nature of the substrate than by certain physical properties that influence soil moisture levels. During February 2012, when sampling took place, the study area had received between 50 and $200 \mathrm{~mm}$ rain, which accounts for more than $75 \%$ of the expected average summer rainfall for the area (South African Weather Service 2012). Moisture was, therefore, not a limiting factor and the chemical nature of the soils, along with other abiotic habitat features, appear to have influenced species richness and composition. In addition to the abiotic conditions such as edaphic features, biotic factors, especially the type of vegetation, can influence diversity and community composition of cryptogamic biota. For example, Rosentreter et al. (2007) documented that vagrant populations of Dermatocarpon occur on poorly drained basalt flats dominated by Artemisia rigida, A. papposa, Antennaria flagellaris and Poa sandbergii. The ecological conditions found at such sites can support completely or partially vagrant life forms in Dermatocarpon and other lichen genera. The differences in vegetation cover of the plant communities at the sampling sites (Sites 1-8) could have created microenvironments that favour specific algal and cyanoprokaryote species assemblages. Sites 1-7 had moderate cover, whereas Site 8 was an open savanna characterised by numerous bare soil patches (serpentine effect).

Twenty different species were identified at Site 8 (serpentine), despite this site showing elevated concentrations of heavy metals, including $\mathrm{Co}, \mathrm{Cr}, \mathrm{Fe}, \mathrm{Mn}$ and $\mathrm{Ni}$ (Table 2). Chroococcus sp., Scytonema ocellatum, Nostoc linckia, Chlorotetraedron sp., Hormotilopsis gelatinosa, Klebsormidium flaccidium, Pleurococcus sp. and Tetracystis elliptica were unique to this site. Metals can be divided into those that are required by organisms in small quantities, such as $\mathrm{Fe}, \mathrm{Cu}$ and $\mathrm{Zn}$, which are essential in some biochemical reactions (Raven et al. 1999), and non-essential metals such as $\mathrm{As}, \mathrm{Pb}$, and $\mathrm{Hg}$, which may cause severe harm to organisms even at very low concentrations because they do not provide any known biochemical function (Monteiro et al. 2012). However, the toxic effects of metallic elements on microalgae are complex and differ markedly among species, depending on the element itself and the prevailing environmental conditions (Monteiro et al. 2012). Stark and Shubert (1979) reported a positive correlation between $\mathrm{Mn}, \mathrm{N}$, $\mathrm{P}$, silica $(\mathrm{Si}), \mathrm{Al}$, zinc $(\mathrm{Zn})$ and $\mathrm{Pb}$ concentrations and algal abundance, and a negative correlation with $\mathrm{Na}, \mathrm{Cd}, \mathrm{Cu}$, lithium (Li), Mo and strontium (Sr). Cyanoprokaryotes have developed efficient strategies for metal uptake and accumulation (Shcolnick and Keren 2006). According to Keren et al. (2002), cyanoprokaryotes are able to accumulate high concentrations of $\mathrm{Mn}$ in the envelope layers of their cells. Whether the high Mn supports the growth of cyanoprokaryotes or reduces competition by other groups that are less tolerant of $\mathrm{Mn}$ was unclear. Soil $\mathrm{pH}$ plays a critical role in the bioavailability of heavy metals (Rajakaruna and Boyd 2008) and, although serpentine Site 7 had high metal concentrations, the relatively higher $\mathrm{pH}$ at this site may have made those metals less bioavailable (Neilson and Rajakaruna 2012). Hence, it was unclear whether the higher algal diversity at this site resulted from metal tolerance or reduced metal toxicity owing to lower metal availability. However, algae are able to grow in the presence of heavy metals as a result of a variety of tolerance mechanisms, for example, binding to cell wall, precipitation in vacuole and synthesis of heavy metal-binding compounds such as proteins, organic acids and phenolic compounds (Metha and Gaur 2005). Serpentine soils are renowned for low $\mathrm{Ca}: \mathrm{Mg}$ ratio; however, DeGrood et al. (2005) found that low $\mathrm{Ca}: \mathrm{Mg}$ ratio does not significantly explain variation in microbial community patterns; also, our study did not show a strong correlation between algal diversity and $\mathrm{Ca}: \mathrm{Mg}$. Microbes may, therefore, be responding to increased soil organic matter concentrations, probably because of the associated increases in nutrient availability and waterholding capacity.

Algae as a group are physiologically heterogeneous, making any generalisation about their soil relations difficult (O'Kelly 1974). However, favourable soil $\mathrm{pH}$, moisture conditions and nutrient content contribute to species diversity and community composition (Shields and Durell 1964). The multivariate analyses did not suggest a distinct species association for serpentine sites (Sites 7 and 8). This was also true for the mafic and ultramafic sites (Sites 3, 4, 5 and 6) as well as the siliciclastic sites (Sites 1 and 2). The lack of a strong correlation with lithic type and a stronger correlation with slope position suggests that the type of slope may be more important in influencing diversity. Site pairs 1 and 2, 3 and 4 as well as 5 and 6 were sampled at different slope positions and, at times, shared similar species associations based on slope position (Fig. 3).

\section{Conclusions}

It seems unlikely that soil chemistry alone was responsible for determining species diversity and no unique algal flora for serpentine soils was confirmed. However, the serpentine soil at Kaapschehoop (Site 8) did have a unique species assemblage, comprising Chroococcus sp., Chlorotetraedron sp., Hormotilopsis gelatinosa, Klebsormidium flaccidium Pleurococcus sp. and Tetracystis elliptica. However, this requires further investigation to determine whether it was a lithic or climatic effect.

Soil features, along with other biotic (vegetation composition) and abiotic (slope, exposure) habitat characteristics, may influence the presence and dominance of some algal and cyanoprokaryote species in harsh edaphic settings. Our results suggested that topography (i.e. slope position), rather than the chemistry of the lithic class (i.e. rock type), was most important in influencing species diversity. However, high concentrations of heavy metals also influenced species richness as well as community composition.

The characterisation of microbial communities using an isolation approach can be biased because this approach tends to favour some groups of microbes over others. Therefore, in the future, we plan to incorporate molecular approaches (Bjelland et al. 2011; Daae et al. 2013) to characterise the diversity of cyanoprokaryotes and soil algae at our sites. Additionally, the ecological heterogeneity within each site should be taken into consideration, because our sampling strategy (i.e. pooling of soil 
samples) did not allow for detecting species that may be restricted to distinct microhabitats found within our sites. A composite sample does not allow for a correlation with biotic and abiotic factors, but gives a general and preliminary view on the diversity at each site. Although our findings are preliminary, the study sets the stage for detailed investigations on the relative importance of edaphic versus other habitat features on algal and cyanoprokaryote diversity and community assembly.

\section{Acknowledgements}

We thank the staff at Eko-Analitika, North-West University, Potchefstroom, for the soil analyses, Christel Pretorius for drawing the map of the study area, and two anonymous reviewers for their useful suggestions to improve the quality of our manuscript.

\section{References}

Alexander EB, Coleman RG, Keeler-Wolf T, Harrison SP (2007) 'Serpentine geoecology of western North America: geology, soils and vegetation.' (Oxford University Press: New York)

ATSDR (Agency for Toxic Substances and Disease Registry) (2008) 'Toxicological profile for aluminium.' (US Department of Health and Human Services, Public Health Service: Atlanta, GA) Available at http:// www.atsdr.cdc.gov/ToxProfiles/tp22.pdf. [Verified 19 August 2014]

Belnap J (2003) The world at your feet: desert biological soil crusts. Frontiers in Ecology and the Environment 1, 181-189. doi:10.1890/1540-9295(2003)001[0181:TWAYFD]2.0.CO;2

Belnap J, Lange OL (2001) 'Biological soil crusts: structure, function and management.' (Springer: Berlin)

Bjelland T, Grube M, Hoem S, Jorgensen SL, Daae FL, Thorseth IH, Ovreås L (2011) Microbial metacommunities in the lichen-rock habitat. Environmental Microbiology Reports 3, 434-442. doi:10.1111/j.1758-2229.2010.00206.x

Blank JG, Green SJ, Blake D, Valley JW, Kita NT, Treiman A, Dobson PF (2009) An alkaline spring system within the Del Puerto Ophiolite (California, USA): a Mars analog site. Planetary and Space Science 57, 533-540. doi:10.1016/j.pss.2008.11.018

Bramwell D, Caujape-Castells J (2011) 'The biology of island flora.' (Cambridge Press: Cambridge, UK)

Brown RM, Larson DA, Bold HC (1964) Airborne algae: their abundance and heterogeneity. Science 143, 583-585. doi:10.1126/science. 143.3606 .583

Cabala J, Rahmonov O, Jablonska M, Teper E (2011) Soil algal colonization and its ecological role in an environment polluted by past $\mathrm{Zn}-\mathrm{Pb}$ mining and smelting activity. Water, Air, and Soil Pollution 215, 339-348. doi:10.1007/s11270-010-0482-1

Cardace D, Meyer-Dombard DR, Olsen A, Parenteau MN (2014) Bedrock and geochemical controls on extremophile habitats. In 'Plant ecology and evolution in harsh environments'. (Eds N Rajakaruna, RS Boyd, TB Harris) pp. 1-32. (Nova Science Publishers: New York)

Chen YN, Wang Q, Li WH, Ruan X (2007) Microbiotic crusts and there interrelations with environmental factors in the Gurbantonggut desert, western China. Environmental Geology 52, 691-700. doi:10.1007/s00254-006-0505-9

Clarke KR, Gorley RN (2001) 'PRIMER v.5: user manual/tutorial.' (PRIMER-E: Plymouth, UK)

Clarke B, Uken R, Reinhardt J (2009) The geometry and emplacement mechanics of a Bushveld complex peridotite body, South Africa. South African Journal of Geology 112, 141-162. doi:10.2113/gssajg.112.2.141

Couté A, Tell G, Therezien Y (1999) Aerophytic Cyanophyceae from New Caledonia. Cryptogamie. Algologie 20, 301-344. doi:10.1016/S0181-1568(00)88147-7

Daae FL, Økland I, Dahle H, Jørgensen SL, Thorseth IH, Pedersen RB (2013) Microbial life associated with low-temperature alteration of ultramafic rocks in the Leka ophiolite complex. Geobiology 11, 318-339. doi:10.1111/gbi.12035

Daghino S, Murat C, Sizzano E, Girlanda M, Perotto S (2012) Fungal diversity is not determined by mineral and chemical differences in serpentine substrates. PLoS ONE 7(9), e44233. doi:10.1371/journal.pone. 0044233

DeGrood SH, Claassen VP, Scow KM (2005) Microbial community composition on native and drastically disturbed serpentine soils. Soil Biology \& Biochemistry 37, 1427-1435. doi:10.1016/j.soilbio.2004.12.013

Ettl H, Gärtner G, Heynig H, Mollenhauer D, Komárek J, Anagnostidis K (1999) 'Süsswasser von Mittleeuropa: Cyanoprokaryota, Teil 1: Chroococcales.' (Gustav Fisher Verlag: Stuttgart, Germany)

Favero-Longo SE, Isocrono D, Piervittori R (2004) Lichens and ultramafic rocks: a review. Lichenologist (London, England) 36, 391-404. doi:10.1017/S0024282904014215

Fernandez-Piñas F, Mateo P, Bonilla I (1995) Ultrastructural changes induced by selected cadmium concentrations in the cyanobacterium Nostoc UAM208. Journal of Plant Physiology 147, 452-456. doi:10.1016/S0176-1617(11)82182-6

Hahs AK, McDonnell MJ (2006) Selecting independent measures to quantify Melbourne's urban-rural gradient. Landscape and Urban Planning 78, 435-448. doi:10.1016/j.landurbplan.2005.12.005

Harrison SP, Rajakaruna N (2011) 'Serpentine: evolution and ecology in a model system.' (University of California Press: Berkeley, CA)

Hauer T (2008) Epilithic cyanobacterial flora of Mohelenská Hadcová steppe nature reseve (western Moravia, Czech Republic) 70 years ago and now. Fottea $\mathbf{8}, 129-132$.

Hindak F (2008) 'Atlas of cyanophytes.' (VEDA: Bratislava, Slovakia)

Hofmann A, Wilson A, Kröner A, Guy B, Beukes N (2012) 'Workshop on craton formation and destruction, post-conference excursion guidebook: early craton formation, stabilisation, plume-related magmatism and meteorite impact (Vredefort, Witwatersrand, Bushveld and Barberton).' (Burlington House: Piccadilly, London) Available at http://www.gssa.org.za/Documents/Craton\%20Formation\%20and\% 20Destruction\%20Excursion\%20Guide.pdf [Verified 27 November 2013]

Hüber-Pestalozzi G (1961) 'Das Phytoplankton des Süsswassers: Systematik und Biologie. Tiel 5: Chlorophyceae (Grünalgen). Ordnung: Volvocales.' (Verlagbuchhandlung: Stuttgart, Germany)

John DM, Whitton BA, Brook AJ (2002) 'Freshwater algal flora of the British Isles: a guide to freshwater and terrestrial algae.' (Cambridge University Press: Cambridge, UK)

Keren N, Kidd MJ, Penner-Hahn JE, Pakrasi HB (2002) A light-dependent mechanism for massive accumulation of manganese in the photosynthetic bacterium Synechocystis sp. PCC 6803. Biochemistry 41, 15 085-15 092. doi:10.1021/bi026892s

Komárek J, Anagnostidis K (2005) 'Cyanoprokaryota: Oscillatoriales.' (Spektrum Akademischer Verlag: Heidelberg, Germany)

Kruckeberg AR (2002) 'Geology and plant life: the effects of landforms and rock type on plants.' (University Washington Press: Seattle, WA)

Krüger GHJ (1978) 'The effect of physico-chemical factors on growth relevant to the mass culture of Microcystis under sterile conditions.' (University of the Orange Free State: Bloemfontein, South Africa)

Langhans TM, Storm C, Schwabe A (2009) Community assembly of biological soil crusts of different successional stages in a temperate sand ecosystem, as assessed by direct determination and enrichment techniques. Microbial Ecology 58, 394-407. doi:10.1007/s00248-009-9532-x

Lukesova A (2001) Soil algae in brown coal lignite post-mining areas in central Europe (Czech Republic and Germany). Restoration Ecology 9, 341-350. doi:10.1046/j.1526-100X.2001.94002.x

Lund JWG (1945) Observations on soil algae. I. The ecology, size and taxonomy of British soil diatoms. Part 1. New Phytologist 44, 196-219. doi:10.1111/j.1469-8137.1945.tb05033.x 
Metha SK, Gaur JP (2005) Use of algae for removing heavy metal ions from wastewater; progress and prospects. Critical Reviews in Biotechnology 25, $113-152$.

Metting B (1981) The systematics and ecology of soil algae. Botanical Review 47, 195-312. doi:10.1007/BF02868854

Michaud AB, Šabacká M, Priscu JC (2012) Cyanobacterial diversity across landscape units in a polar desert: Taylor Valley, Antarctica. FEMS Microbiology Ecology 82, 268-278. doi:10.1111/j.1574-6941.2012.01297.x

Monteiro MN, Castro PML, Macata FX (2012) Metal uptake by microalgae: underlying mechanism and practical application. Biotechnology Progress 28, 299-311. doi:10.1002/btpr.1504

Mucina L, Rutherford MC (2006) 'The vegetation of South Africa, Lesotho and Swaziland. Strelitzia 19.' (South African National Biodiversity Institute: Pretoria, South Africa)

Mühlsteinová R, Johansen JR, Pietrasiak N, Martin MP (2014) Polyphasic characterization of Kastovskya adunca gen. nov. et comb. nov. (Cyanobacteria: Oscillatoriales) from desert soils of the Atacama Desert, Chile. Phytotaxa 163, 216-228. doi:10.11646/phytotaxa.163.4.2

Neilson S, Rajakaruna N (2012) Roles of rhizospheric processes and plant physiology in phytoremediation of contaminated sites using oilseed Brassicas. In 'The plant family Brassicaceae: contribution towards phytoremediation. Environmental pollution book series. Vol. 21'. (Eds NA Anjum, I Ahmad, ME Pereira, AC Duarte, S Umar, NA Khan) pp. 313-330. (Springer: Dordrecht, The Netherlands)

Norman N, Whitfield G (2006) 'Geological journeys: a traveller's guide to South Africa's rocks and landforms.' (Struik: Cape Town, South Africa)

NSSSA (Non-Affiliated Soil Analysis Work Committee, Soil Science Society of South Africa) (1990) 'Handbook of standard soil testing methods for advisory purposes.' (Soil Science Society of South Africa: Pretoria, South Africa)

O'Dell RE, Rajakaruna N (2011) Intraspecific variation, adaptation, and evolution. In 'Serpentine: evolution and ecology in a model system'. (Eds SP Harrison, N Rajakaruna) pp. 97-137. (University of California Press: Berkeley, CA)

O'Kelly JC (1974) Inorganic nutrients. In 'Algal physiology and biochemistry'. (Ed. WDP Stewart) pp. 610-635. (Blackwell: London)

Oline DK (2006) Phylogenetic comparisons of bacterial communities from serpentine and non-serpentine soils. Applied and Environmental Microbiology 72, 6965-6971. doi:10.1128/AEM.00690-06

Orlekowsky T, Venter A, Van Wyk F, Levanets A (2013) Cyanobacteria and algae of gold mine tailings in the Northwest Province of South Africa. Nova Hedwigia 97, 281-294. doi:10.1127/0029-5035/2013/0117

Pinto E, Sigaud-Kutner TCS, Leităo MAS, Okamoto OK, Morse D, Colepicolo P (2003) Heavy metal-induced oxidative stress in algae. Journal of Phycology 39, 1008-1018. doi:10.1111/j.0022-3646.2003.02-193.x

Proctor J, Woodell SRJ (1975) The ecology of serpentine soils. Advances in Ecological Research 9, 255-366. doi:10.1016/S0065-2504(08)60291-3

Rajakaruna N, Boyd RS (2008) The edaphic factor. In 'The encyclopedia of ecology. Vol. 2'. (Eds SE Jorgensen, B Fath) pp. 1201-1207. (Elsevier: Oxford, UK)

Rajakaruna NB, Harris TB, Alexander EB (2009) Serpentine geoecology of eastern North America: a review. Rhodora 111, 21-108. doi: $10.3119 / 07-23.1$

Rajakaruna N, Knudsen KA, Fryday RE, O'Dell N, Pope F, Olday C, Woolhouse S (2012) Investigation of the importance of rock chemistry for saxicolous lichen communities of the New Idria serpentinite mass, San Benito County, California, USA. Lichenologist 44, 695-714 doi:10.1017/S0024282912000205

Rajkumar M, Ma Y, Freitas H (2008) Characterization of metal-resistant plant growth promoting Bacillus weihenstephanensis isolated from serpentine soil in Portugal. Journal of Basic Microbiology 48, 500-508. doi:10.1002/jobm.200800073
Raven JA, Evans MCW, Korb RE (1999) The role of trace metals in photosynthetic electron transport in $\mathrm{O}_{2}$ evolving organisms. Photosynthesis Research 60, 111-150. doi:10.1023/A:1006282714942

Reddy RA, Balkwill K, Mclellan T (2001) Is there a unique serpentine flora on the Witwatersrand? South African Journal of Science 97, 485-495.

Řeháková K, Chlumská Z, Doležal J (2011) Soil cyanobacterial and microalgal diversity in dry mountains of Ladakh, NW Himalaya, as related to site, altitude and vegetation. Microbial Ecology 62, 337-346. doi:10.1007/s00248-011-9878-8

Rosentreter R, McCune B (1992) Vagrant Dermatocarpon in western North America. The Bryologist 95, 15-19. doi:10.2307/3243779

Rosentreter R, Bowker M, Belnap J (2007). A field guide to biological soil crusts of western US drylands.' (US Government Printing Office: Denver, $\mathrm{CO})$

Schuster RM (1983) Phytogeography of the bryophytes. In 'New manual of bryology'. (Ed. RM Schuster) pp. 463-626. (Hattori Botanical Laboratory: Nichinan, Japan)

Shcolnick S, Keren N (2006) Metal homeostasis in cyanobacteria and chloroplasts. Balancing benefits and risks to the photosynthetic apparatus 1. Plant Physiology 141, 805-810. doi:10.1104/pp.106.079251

Shields LM, Durell LW (1964) Algae in relation to soil fertility. Botanical Review 30, 92-128. doi: 10.1007/BF02858614

Siebert SJ, Van Wyk AE, Bredenkamp GJ (2002) The physical environment and major vegetation types of Sekhukhuneland, South Africa. South African Journal of Botany 68, 127-142.

Soil Classification Working Group (1991) 'Soil classification: a taxonomic system for South Africa.' (Department of Agricultural Development: Pretoria, South Africa)

South African Weather Service (2012) Rainfall maps. Climate Summary of South Africa 23, 4-5.

Southworth D, Tackaberry LE, Massicotte HB (2014) Mycorrhizal ecology on serpentine soils. Plant Ecology \& Diversity 7, 445-455. doi:10.1080/17550874.2013.848950

Stark TL, Shubert LE (1979) Algal colonization on reclaimed surface mined area in western North Dakota. In 'Ecology and coal resource development. Vol. 2'. (Ed. MK Wali) pp. 652-660. (Pergamon Press: New York)

Starks TL, Shubert LE (1982) Colonization and succession of algae and soil-algal interactions associated with disturbed areas. Journal of Phycology 18, 99-107. doi:10.1111/j.1529-8817.1982.tb03162.x

Starmach K (1963) 'Flora Slodkowodna Polski. Rosliny Slodkovodne. Wstep Ogólny I Zarys Method Badania.' (Panstwowe Wyd-wo Nauk: Warszawa, Poland)

Stein JR (1973) 'Handbook of phycological methods and culture methods and growth measurements.' (Cambridge University Press: Cambridge, UK)

Suzuki S, Ishii S, Wu A, Cheung A, Tenney A, Wanger G, Kuenen JG, Nealson KH (2013) Microbial diversity in the cedars, an ultrabasic, ultrareducing, and low salinity serpentinizing ecosystem. Proceedings of the National Academy of Sciences, USA 110, 15 336-15341. doi: $10.1073 /$ pnas. 1302426110

Taylor JC, Harding WR, Archibald CGM (2007) An illustrated guide to some common diatom species from South Africa. WRC Report TT282/07. (Water Research Commission: Pretoria South Africa)

Ter Braak CJF, Smilauer P (1998) 'CANOCO reference manual and user's guide to Canoco for Windows: software for canonical community ordination (version 4).' (Microcomputer Power: Ithaca, NY)

Terlizzi DE, Karlander EP (1979) Soil algae from a Maryland serpentine formation. Soil Biology \& Biochemistry 11, 205-207. doi:10.1016/0038-0717(79)90102-0

US EPA (1996) 'Method 3050B. Acid digestion of sediments, sludges, and soils.' Available at http://www.epa.gov/wastes/hazard/testmethods/sw 846/online/3_series.htm. [Verified 1 August 2014]

Wehr JD, Sheath RG (2003) 'Freshwater algae of North America, ecology and classification.' (Academic Press: London) 